\title{
The Impacts of Feed and Fodder Development Programmes on Livestock Rearing by Farmers in North Karnataka
}

\author{
B. Veena* and B. Nagratna \\ Department of Agricultural Extension Education, College of Agriculture, \\ Dharwad-580 005, India \\ *Corresponding author
}

\begin{tabular}{|l}
\hline Ke y w or d s \\
Azolla production, \\
Goshala, fodder \\
banks and training \\
program
\end{tabular}

\section{Introduction}

Crop cultivation, animal husbandry and other allied activities has been the core livelihood for majority of the rural people since time immemorial. Animal husbandry in particular provides productive employment, especially self-employment and the most valuable supplementary income to a vast majority of rural households dominated by small and

\begin{abstract}
The prime objective of this research is Assess the impacts of feed and fodder development programmes on livestock farmers of North Karnataka of Belagavi, Baglkote and Gadag district. All the feed and fodder development programmes implemented in study districts for the period 2007-2016 were taken for the study. The programmes are; Fodder minikits distribution, Trainings and demonstrations on feed and fodder, azolla and silage making, Chaff cutter distribution and Fodder banks and Goshalas (Cow shelters). Benefits realized by respondents from each programme were listed and presented by calculating frequencies and percentages. This study conducted following ex-post facto research design during 2016-17. For this purpose 120 livestock farmers consisted 60 farmers benefited from different feed and fodder development programmes and 60 non-beneficiary livestock farmers were selected. Training programmes were attended by 26 sampled respondents out of 60. All of them expressed that these programmes helped them to increase their knowledge level on azolla production and silage making. Twenty five sampled respondents were benefitted from fodder minikits distribution program. Twenty one sampled respondents were benefitted by chaff cutter distribution program. Almost all of them $(95.23 \%)$ expressed that getting chaff cutter helped them to reduce labour involved and ten respondents were benefitted by program on fodder banks and Goshala. Eight of them expressed that it helped them to obtain fodder in drought year.

A B S T R A C T
\end{abstract}

marginal farmers and landless labourers. Livestock provides increased economic stability to the poor masses. They act as a cash buffer in case of small stock and as captive reserve in case of larger stock. Livestock provides quality animal protein to human population in the form of milk, eggs, meat and value added products. They provide draught power for agricultural operations, organic manure for agriculture and raw 
materials like skin, hides, blood, bone, hoof, horn, etc. for various industries.

India's livestock sector is one of the largest in the world both for livestock numbers and production. The contribution of livestock to agriculture GDP is 15.10 per cent and accounts for 4.11 per cent to total GDP. The productivity of livestock is however low owing to poor feeding practices followed by farmers. Major part (65-70\%) of livestock farming cost is attributed to feeding only. India with 2.3 per cent share of global geographical area supports nearly 20 per cent of the livestock population of the world, notably among them are cattle (16\%), buffalo $(55 \%)$, goat $(20 \%)$ and sheep $(5 \%)$. The desired annual growth of agriculture sector at 4 per cent can also be accomplished by enhancing productivity from the livestock sector (Islam et al., 2016). Improving productivity in a huge population of low producing animals is one of the major challenges. The average annual milk yield of Indian cattle is $1172 \mathrm{~kg}$ which is only about 50 per cent of the global average and much less than in New Zealand (3343 kg), Australia $(5600 \mathrm{~kg})$, UK (7101 kg), US (9332 kg) and Israel (10214 kg) (Birthal and Taneja, 2006). This would require a steady supply of fodder for supporting the livestock population. But in India, the availability of fodder, both dry and green, has not been commensurate with the requirement. Whereas, the projected requirement has showed that 64.21 per cent (728 million tonnes) green fodder and 24.81 per cent (157 million tonnes) dry fodder deficit is estimated (Datta, 2013). It has resulted in a projected shortage of more than 60 per cent in green fodder and nearly 23 per cent in dry fodder by 2020. Converted into absolute terms, this deficit works out to 728 million tons in respect of green fodder and 157 million tons in respect of dry fodder. Scenario in Karnataka is also same.
Scenario of feed and fodder requirement and availability in India (Planning commission, 2016) (In million tonnes).

\begin{tabular}{|l|l|l|l|l|l|l|}
\hline Year & \multicolumn{2}{|l|}{ Supply } & \multicolumn{2}{l|}{ Demand } & \multicolumn{2}{l|}{ Deficit (\%) } \\
\hline & Green & Dry & Green & Dry & Green & Dry \\
\hline 2015 & 400.6 & 466 & 1097 & 609 & 63.50 & 23.56 \\
\hline
\end{tabular}

\section{About feed and fodder development programmes}

Though feed and fodder is one of the most important contributing factors for the growth of livestock sector, development of this sector has not received the required level of focus in the past. It is estimated that the 60-70 per cent of total cost in livestock production is due to feed and fodder. Any attempt towards enhancing feed availability and economizing the feed cost would result in increased margin of profits to livestock owners. Adequate availability of livestock feed and fodder both quantitatively as well as qualitatively is going to be one of the key inputs in the growth of livestock sector during $12^{\text {th }}$ plan period and beyond. With greater focus being given towards productivity enhancement in the recent years, it becomes all the more essential for ensuring the availability of quality feed and fodder to sustain higher productivity of animals.

The schemes so developed by Government has not only to address the issue of green fodder seed production but also encompass other aspects like area expansion of green fodder, fodder conservation, fodder densification, establishment of fodder banks, and nutritional enhancement of crop residues, capacity building, and extension. The ongoing schemes on 'Feed and Fodder Development' are fodder minikits distribution, trainings and demonstrations on feed and fodder, azolla and silage making, chaff cutter distribution, fodder banks and Goshalas (Cow shelters). The specific objective of the study is as follows 
The specific objective of the study is as follows

Impact of feed and fodder development programmes on livestock rearing by farmers

\section{Materials and Methods}

In North Karnataka, three districts having highest (Belagavi), medium (Gadag) and lowest (Bagalkote) livestock population were selected for the study. From each district, one taluka was selected based on highest livestock population. From each taluka, four villages were selected based on more number of beneficiaries of feed and fodder development programmes. From each village, five beneficiary and five non-beneficiary respondents were selected randomly. So the study covered three districts, three talukas and twelve villages. The total sample size for the study was 120 .

Pre-tested and standardized interview schedule was used for data collection from 60 beneficiaries and 60 non-beneficiaries of feed and fodder development programmes of Belagavi, Bagalkote and Gadag districts through personal interview technique. Here for studying impact of the feed and fodder development programmes 60 beneficiary livestock farmers response consideredThe appropriate statistical procedures such as frequency, percentage were employed to analyze the data.

\section{Results and Discussion}

Table 1 shows impact of different feed and fodder programmes on livestock farmers.Four programmes related to feed and fodder were covered under the study. They were training programmes on feed, fodder, azolla and silage making, fodder minikits, chaff cutter, fodder banks and Goshalas. Impact of training program on feed, fodder, azolla and silage making units was assessed in terms of their learning and psychological aspects. It is to be noted that content for all the training programmes varied. Nearly half of the respondents $(46.15 \%)$ expressed that trainings helped them to increase their confidence on efficient feed management, knowledge on different AHVS schemes, procedure to obtain benefits from programmes, scientific management of animals, procedure to avail loan from bank and motivational level to perform better. Increase in many dimensions of individual's behavioral aspects is what expected from capacity building programmes. There will be difference in an individual's capacity to learn and grasp things. This difference in learning might have resulted in only 46.15 per cent respondents mentioning above benefits from training programmes. Similar per cent $(46.15$ $\%)$ of respondents also expressed that trainings gave them opportunities to interact with like-minded fellow farmers and to earn extra income. These two benefits were off shoots of an actual training program. Azolla production and silage making are important to improve the availability of quality fodder and feed.Low-cost silage technology increases milk production and farmers income (Khaleduzzaman et al., 2011). Azolla could be used as feed ingredient with milk yields and fat percentage being maintained at the same levels as with conventional feeds (Nikkhah and Motaghi, 1992). Replacement of groundnut cake with azolla at 50 per cent level for 90 days improved the digestibility of major nutrients and resulted in higher weight gain in buffalo calves (Indira et al., 2009). Cent per cent of respondents who attended trainings expressed that there is an increase in their knowledge level on these two aspects.

Fodder minikits is a program where in fodder seed of different varieties are distributed to farmers. Utilization of seed through successful cultivation depends on individuals 
interest in farming coupled with other resources and weather parameters. This could be the reason for only 44.00 per cent farmers expressing that the minikits helped them to increase green fodder availability. Only one fourth of them mentioned that minikits helped to reduce feed cost and labour cost. Many farmers do not practice feeding expensive concentrate feeds to their animals. Similarly, some farmers might not put extra labour to fetch green fodder from available area. This could be the reason for only quarter of the respondents mentioning these benefits. At present, livestock is receiving 51, 38, 3, 6 and 2 per cents of nutrients from green fodder, crop residues, grazing vacant lands, postharvest grazing, cereal by products and oilcakes and meals, respectively. The gap between requirement and availability of nutrients could be minimized both through proper fodder research and extension policies in terms of better quality seed, seed rate, improved agronomic practices and improved inputs (fertilizers, water and pesticides). Agro industrial byproducts and non-conventional feed resources could be used for feeding of livestock if farmers are trained to do so. Situation may be further improved if fodder conservation techniques are introduced in livestock feeding systems (Sarwat et al., 2002). Milk production of bovine population significantly depends upon the good quality of green and dry fodders. In this connection, it is suggested to supply improved seed of fodders to farmers in irrigated and unirrigated cultivated areas (Pandey, 1995).

Vast per cent of respondents mentioned that chaff cutter reduced labour charge $(95.23 \%)$ and wastage level $(85.71 \%)$. Farmers of the study area practice use of ilagi (sort of big knife) to cut stovers of sorghum and maize which is labour consuming. It also cuts stover into big pieces (1 feet length) leading to wastage. However, chaff cutter addresses both these issues. Many of the chaff cutters were given to beneficiaries on subsidy basis ranging from 50.00 to 80.00 per cent depending on the category to which farmers belongs. The average cost saved however, is ' $14,926 \pm 2590.29$. The findings are in accordance with the studies conducted by Dashawant (2007).

Availability of fodder especially in drought condition reduces considerably at times forcing farmers to resort to distress selling of animals. Program on fodder banks and Goshalas address these issues as 80.00 per cent beneficiary respondents mentioned that they were benefited by getting fodder at low price in drought by these programmes. One fifth per cent of beneficiary respondents expressed that Goshalas took complete responsibility of their animals in drought. In study area, livestock are maintained to meet out contingency situations apart from getting milk and manure. Selling animals in drought at low price devoid them an opportunity to have this arrangement to face emergency situation. Purchasing new animals is a costly affair for them. So maintaining animals in drought is a very important activity to save farmers from financial burden.

Table 2 shows presents results on impact of all feed and fodder development programmes together on livestock rearing in terms of assets generation, income generation, services availed from government and capacity building.

Impact of feed and fodder development programmes were assessed against four parameters. These parameters were asset generation, income generation, services availed and extent of increase in capacity of respondents in livestock management.

Among 60 beneficiaries of feed and fodder development programmes, 21 respondents were benefited by procuring chaff cutter. This 
amounts to only 35.00 per cent of the total beneficiary respondents. The average amount of fund allocated to chaff cutter ranged from 11 to 14 per cent in Belagavi and Bagalkote districts and only 2 to 4 per cent in Gadag district both in normal rainfall and drought years. However, fund allocated for programmes like minikits and trainings was much higher.

The limited fund allocation for chaff cutter could have restricted number of beneficiaries to only 35.00 per cent. In southern states of India, chaffing fodder is not practiced by the farmers and therefore use of chaff cutters is not as common as in North India. So, only limited fund might have been allocated for this programme (Rao et al., 1995). However, this is a very good asset for livestock farmers as it helps to efficiently use available fodder besides saving labour.

Fodder and feed development programmes benefited respondents to generate additional income. Scientific management and feeding of fodder helped to improve livestock productivity by which increased income was witnessed by 41.67 per cent of respondents.

A small change in feeding pattern of animals for instance adding leguminous fodder would enhance milk production besides improvement in the health of the animal. Azolla is a very rich protein source. Silage enhances nutritional composition of fodder. However, for these programmes, very less fund was allocated. This could be the reason for only few respondents expressing earning of addition income from livestock due to feed and fodder development programmes.

Fodder banks and Goshalas were the programmes taken up only from 2013 onwards. Fund allocation for these programmes was less in Belagavi and
Bagalkote district. These are the districts represent highest and medium livestock population. Gadag district provided contrasting scenario as large amount of fund was allocated for these programmes.

Recent introduction of these programmes and allocation of funds could be the reasons for only 13.33 per cent respondents availing benefits from fodder banks and only 3.33 per cent getting benefits from Goshala. Another service availed was training programmes as 43.33 per cent attended it. Training program is a regular feature and it received good proportion of fund allocation.

Participation in fodder and feed development especially training programmes helped beneficiaries to increase their capacity on various fronts. The extent of increase in capacity on different available AHVS schemes was 43.33 per cent. Similarly extent of increase was 37.92 per cent for scientific management of animals, 36.67 per cent for scientific feeding of animals, 35.83 per cent on procedures for availing loan from banks and 34.17 per cent to get benefits from AHVS schemes. Training programmes which are the means to enhance capacity received funds regularly and also got good portion of fund.

Learning is the result of interaction of factors like attention and interest of the learner besides the way training programmes are designed and conducted. Extent of increase in the capacity through trainings could be enhanced further by making learners more receptive through well designed training programmes.

These programmes enhanced confidence level of beneficiaries on efficient feed management by 37.50 per cent and motivational level by 34.17 per cent indicating further scope to improve upon training programmes. 
Table.1 Impact of different feed and fodder programmes in terms of benefits obtained by beneficiary farmers

\begin{tabular}{|c|c|c|c|}
\hline \multirow{2}{*}{$\begin{array}{l}\text { Sl. } \\
\text { No. }\end{array}$} & \multirow[t]{2}{*}{ Particulars } & \multicolumn{2}{|c|}{ Respondents } \\
\hline & & Frequency & Percentage \\
\hline 1. & $\begin{array}{l}\text { Training programmes on feed, fodder, azolla and } \\
\text { silage making units }(n=26)\end{array}$ & & \\
\hline a. & $\begin{array}{l}\text { Increased confidence level on efficient feed } \\
\text { management }\end{array}$ & 12 & 46.15 \\
\hline b. & $\begin{array}{l}\text { Increased knowledge on different available AHVS } \\
\text { schemes }\end{array}$ & 12 & 46.15 \\
\hline c. & $\begin{array}{l}\text { Increased knowledge on procedure required to get } \\
\text { benefits from schemes }\end{array}$ & 12 & 46.15 \\
\hline d. & $\begin{array}{l}\text { Increased knowledge on scientific management of } \\
\text { animals and animal based enterprise }\end{array}$ & 12 & 46.15 \\
\hline e. & Increased knowledge on scientific feeding of animals & 12 & 46.15 \\
\hline f. & $\begin{array}{l}\text { Increased knowledge on availing loans from banks } \\
\text { and financial institutions }\end{array}$ & 12 & 46.15 \\
\hline g. & $\begin{array}{l}\text { Gave an opportunity to establish contacts with the } \\
\text { AHVS department }\end{array}$ & 12 & 46.15 \\
\hline h. & $\begin{array}{l}\text { Gave an opportunity to interact with like-minded } \\
\text { farmers }\end{array}$ & 12 & 46.15 \\
\hline i. & Increased motivational level to perform better & 12 & 46.15 \\
\hline j. & Opportunity to earn extra income & 12 & 46.15 \\
\hline k. & Increased knowledge on azolla production & 26 & 100.00 \\
\hline I. & Increased knowledge on silage making units & 26 & 100.00 \\
\hline 2. & Fodder minikits $(\mathrm{n}=\mathbf{2 5})$ & & \\
\hline a. & Increased availability of green fodder & 11 & 44.00 \\
\hline b. & Reduced feed cost & 6 & 24.00 \\
\hline c. & Reduce labour cost & 6 & 24.00 \\
\hline d. & Increase in milk yield & 1 & 4.00 \\
\hline e. & No cost incurred in purchase of seeds & 1 & 4.00 \\
\hline 3. & Chaff cutter $(\mathrm{n}=21)$ & & \\
\hline a. & Reduced labour charge & 20 & 95.23 \\
\hline b. & Reduce wastage & 18 & 85.71 \\
\hline c. & Time saving & 3 & 14.28 \\
\hline d. & Average cost saved (') & $\begin{array}{r}14,926 \\
+590.29\end{array}$ & \\
\hline 4. & Fodder banks and Goshala $(\mathrm{n}=10)$ & & \\
\hline a. & $\begin{array}{l}\text { Helped to get fodder in drought condition and got } \\
\text { fodder at low cost price }\end{array}$ & 8 & 80.00 \\
\hline b. & Animals are wholly taken care of by government & 2 & 20.00 \\
\hline
\end{tabular}


Table.2 Impact of all feed and fodder development programmes on livestock farmers

\begin{tabular}{|c|c|c|c|}
\hline Sl. No. & Impact & Frequency & Percentage \\
\hline 1 & Assets generation & & \\
\hline a. & Chaff cutter & 21 & 35.00 \\
\hline 2. & Income generation & & \\
\hline a. & Increased income by sale of milk & 10 & 16.67 \\
\hline b. & $\begin{array}{l}\text { Increased income due to improvement in livestock } \\
\text { productivity }\end{array}$ & 25 & 41.67 \\
\hline c. & Increased income due to sale of kids & 6 & 10.00 \\
\hline 3. & Services availed from government & & \\
\hline a. & Fodder from fodder banks & 8 & 1.33 \\
\hline b. & Protected animals during distress through Goshala & 2 & 3.33 \\
\hline c. & Trainings attended & 26 & 43.33 \\
\hline 4 & Extent of increase in capacity on $(\%)$ & \multicolumn{2}{|c|}{ Percentage } \\
\hline a. & Different available AHVS* schemes & \multicolumn{2}{|c|}{43.33} \\
\hline b. & $\begin{array}{l}\text { Scientific management of animals and animal based } \\
\text { enterprise }\end{array}$ & \multicolumn{2}{|c|}{37.92} \\
\hline c. & Scientific feeding of animals & \multicolumn{2}{|c|}{36.67} \\
\hline d. & Availing loans from banks and financial institutions & \multicolumn{2}{|c|}{35.83} \\
\hline e. & Procedure required to get benefits from schemes & \multicolumn{2}{|c|}{34.17} \\
\hline f. & $\begin{array}{l}\text { Increased confidence level on efficient feed } \\
\text { management }\end{array}$ & \multicolumn{2}{|c|}{37.50} \\
\hline g. & Increased motivational level to perform better & \multicolumn{2}{|c|}{34.17} \\
\hline
\end{tabular}

AHVS: Animal Husbandry and Veterinary Services

Table.3 Impact of programmes on livestock farmers by comparing annual livestock income with herd size

\begin{tabular}{|c|c|c|c|c|c|}
\hline \multirow{3}{*}{$\begin{array}{l}\text { Sl. } \\
\text { No. }\end{array}$} & \multirow[t]{3}{*}{ Particulars } & \multirow{2}{*}{\multicolumn{2}{|c|}{$\begin{array}{c}\text { Beneficiary } \\
n_{1}=60\end{array}$}} & \multirow{2}{*}{\multicolumn{2}{|c|}{$\begin{array}{c}\text { Non-beneficiary } \\
n_{2}=60\end{array}$}} \\
\hline & & & & & \\
\hline & & Frequency & Percentage & Frequency & Percentage \\
\hline \multirow[t]{6}{*}{1} & Herd size (ACU's) & & & & \\
\hline & Small (1-5) & 31 & 51.67 & 20 & 33.33 \\
\hline & Medium (6-10) & 28 & 46.67 & 32 & 53.33 \\
\hline & Big (11-15) & 1 & 1.67 & 8 & 13.34 \\
\hline & Mean & \multirow{2}{*}{\multicolumn{2}{|c|}{$\begin{array}{l}5.21 \\
0.36\end{array}$}} & \multirow{2}{*}{\multicolumn{2}{|c|}{$\begin{array}{l}7.02 \\
0.44\end{array}$}} \\
\hline & SE & & & & \\
\hline \multirow[t]{6}{*}{2} & $\begin{array}{l}\text { Income by livestock } \\
\text { (Annually in `) }\end{array}$ & & & & \\
\hline & Low $(1,000-12,000)$ & 27 & 45.00 & 39 & 65.00 \\
\hline & Medium $(13,000-24,000)$ & 20 & 33.33 & 21 & 35.00 \\
\hline & High (25,000 and above) & 13 & 21.67 & 00 & 0.00 \\
\hline & Mean & \multirow{2}{*}{\multicolumn{2}{|c|}{$\begin{array}{c}16908.33 \\
1422.26\end{array}$}} & \multirow{2}{*}{\multicolumn{2}{|c|}{$\begin{array}{c}10750.00 \\
654.67\end{array}$}} \\
\hline & SE & & & & \\
\hline
\end{tabular}


Table 3 shows that Impact of programmes on livestock farmers by comparing annual livestock income with herd size more than half $(51.67 \%)$ of the beneficiary respondents possessed small herd followed by 46.67 per cent possessed medium herd size and 1.67 per cent possessed big herd size. The mean herd size possessed by beneficiary respondents was $5.21 \pm 0.36$ Adult Cattle Units (Table 3). Among non-beneficiaries, more than half $(53.33 \%)$ of the respondents possessed medium herd followed by one third $(33.33 \%)$ of the respondents possessed small herd and 13.34 per cent of the respondents possessed big herd size (Table 3). The mean herd size possessed by non-beneficiary respondents was $7.02 \pm 0.44$ Adult Cattle Units Table 3 . Less than half $(45.00 \%)$ of the beneficiary respondents had low level of income by livestock followed by one third $(33.33 \%)$ had medium income from livestock and 21.67 per cent of the respondents had high income from livestock. The average annual income from livestock of beneficiary respondents was $16908.33 \pm 1422.26$. Among non-beneficiary respondents 65.00 per cent had low annual income and 35.00 per cent had medium annual income from livestock. The average annual income from livestock of nonbeneficiary respondents was ' $10750.00 \pm$ 654.67.

Herd size with income obtained by livestock was compared to know the impact of programmes on beneficiary respondents and non-beneficiary respondents. The average herd size of beneficiary respondents was smaller $(5.21 \pm 0.36$ ACUs $)$ than that of nonbeneficiary respondents $(7.04 \pm 0.44$ ACUs $)$. Income earned from livestock was more ( $16908.33 \pm 1422.26)$ for beneficiary respondents than income earned from livestock by non-beneficiary respondents (' $10750.00 \pm 654.67)$. This could be attributed to the good feeding practices, good management practices like efficient use of labour and fodder by beneficiary respondents helping them to improve livestock productivity. There is an increase in milk production by feeding green forage. All farmers can get profit from producing and feeding green fodder and there will be increase in income by livestock to the farmers (Misra et al., 2006). Training programmes on dairy farming through KrishiVigyan Kendra were able to increase the profit of the beneficiary dairy farmers from their enterprise (Singh et al., 2015).

In conclusion, many of the present feed and fodder development programmes identify farmers as beneficiaries based on caste and size of land holding. Along with these two factors efforts must be made to identify livestock farmers with enough experience in livestock rearing having good extension contacts and mass media exposure as these factors expressed positive relationship with benefits derived from feed and fodder programmes. Such efforts will broaden the base of target group and help to obtain more benefits from these programmes. Lack of awareness about feed and fodder development programmes and also about benefits of participating in such programmes was one findings of the study. Utilization of various mass media along with Information Communication Technologies must be advocated by the Animal Husbandry Department to generate more awareness about different fodder programmes. This will help to reach the benefits to the unreached livestock farmers.

\section{References}

Khaleduzzaman, A. B. M., Akbar, M. A. and Shamsuddin, M, 2011, Low-cost silage technology increases milk production and farmers income in north-western districts of Bangladesh. Successes and failures with animal nutrition practices 
and technologies in developing countries. FAO Electronic Conference, 1-30 September 2010, pp. 91-96.

Nik-Khah, M. and Motaghi-Talab, 1992, The use of Azolla in lactating cows, Iranian J. Agric. Sci, 23: 47-56.

Indira, D., Sarjan Rao, K., Suresh, J., Venugopal, N. K. and Ravi, A., 2009, Azolla (A. pinneta) as feed supplement in buffalo calves on growth performance. Indian J. Anim. Nutri, 26 (4): 345-348.

Sarwat, N. M., Noor Muhammad and Qumar, I. A., 2002, Effect of growth stages on the yield an quality of forage grasses. Pakistan J. Agric. Res., 17 (2): 145-147.

Pandey, U. K., 1995, the livestock economy in India: A profile. Indian J. Agric. Econ., 50 (3): 246-282.

Dashawant, J. B., 2007, Impact of Karnataka VikasGrameena Bank on agriculture development of beneficiary farmers. $M$. Sc. (Agri.) Thesis, Univ. Agric. Sci.,
Dharwad, Karnataka (India).

Rao, S. V. N., Van Den Ban, A. W., Rangnekar, D. V. and Ranganathan, K., 1995, Indigenous technical knowledge and livestock. In: Kiran Singh and J. B. Schiere, eds. Handbook for straw feeding system.

Singh, S. P., Singh, S. K and Singh, B. R., 2015, Buffalo farming profitability in beneficiaries and non- beneficiaries dairy farmers of Krishi Vigyan Kendra. Asian J. Dairy \& Food Res., 34 (1) 2015: 28-31.

Misra, A. K., Rama Rao, C. A., Subrahmanyam, K. V., Vijay SankarBabu, M., Shivarudrappa, B. and Ramakrishna, Y. S., 2006, Experiences on participatory action research for enhancing productivity of dairy animals in rain fed agro-ecosystem of India. SAT eJournal, 2(1): 1-14.

\section{How to cite this article:}

Veena, B. and Nagratna, B. 2019. The Impacts of Feed and Fodder Development Programmes on Livestock Rearing by Farmers in North Karnataka. Int.J.Curr.Microbiol.App.Sci. 8(02): 1738-1746. doi: https://doi.org/10.20546/ijcmas.2019.802.205 